\title{
WILLIAM FRANK MARPLES
}

William Frank Marples died in San Diego, California, USA, in October 1985. He was born in Birmingham on 14th February 1907 and educated at King Edward's School, where his father, Percy: Morris Marples, was Senior Mathematics Master. P. M. Marples, in addition to teaching, became an AIA and produced a considerable supply of mathematical students from King Edward's School to go into the Profession. It was not, therefore, surprising when W. F. Marples, on leaving school, joined the Britannic Assurance Co. Ltd. to take the actuarial examinations and later qualified as a Fellow in 1935. He was very well known indeed to actuaries of an earlier generation since, apart from lectures at Staple Inn, there was virtually no actuarial tuition and his father set up 'The Marples Classes' to provide a series of correspondence courses for students taking the examinations. On the death of his father in 1932, W. F. Marples took over 'The Marples Classes' and very quickly became known to all the students who were taking the examinations at that time. In the Session 1938-39 the Actuarial Tuition Service was established under the joint control of the Institute and the Faculty of Actuaries, 'The Marples Classes' were taken over and W. F. Marples became Secretary of the Service. A much larger panel of tutors was then appointed to set to work with the preparation of a completely revised set of lessons, notes, texts and solutions.

In 1940, W. F. Marples resigned from the Tuition Service and was succeeded by H. W. Haycocks. He then joined Duncan C. Fraser in Liverpool as a Partner, to form the firm of Duncan C. Fraser \& Co. and continued in that capacity until 1950, when he emigrated to the United States and joined the firm of George B. Buck in New York. He worked for a number of firms of consulting actuaries in the United States and was still in practice at the time of his death.

He submitted two papers to the Institute, namely 'An Analysis of a Pension Fund' in JIA 73, and 'The Effect of Changed Economic Conditions and State Insurance on Private Pension Fund Benefits' in JIA 74. He also contributed a paper to the Faculty jointly with myself, entitled 'Pension Funds: Some Practical Points', which appears in TFA 19.

He was a man of very considerable enthusiasm and energy in everything in which he was involved. He had a happy family life with his wife Norah. who survives him. and four children.

GEOFFREY HEYWOOD 